\title{
Upaya Meningkatkan Hasil Belajar Siswa Pada Materi Bangun Ruang Sisi Datar dengan Menggunakan Pembelajaran Kooperatif Type Jigsaw dan Media Benda Asli
}

\section{Efforts to Improve Student Learning Outcomes in Material Building Flat-Side Space by using Cooperative Learning Type Jigsaw and Media Original Objects}

\author{
Cumiati \\ SMP Negeri 2 Jatinangor, Sumedang, Jawa Barat, Indonesia \\ Cumiati64@gmail.com
}

Naskah diterima tanggal 22/02/2019, direvisi akhir tanggal 22/04/2019, disetujui tanggal 30/04/2019

\begin{abstract}
Abstrak
Tujuan penelitian yaitu meningkatkan hasil belajar dan aktivitas siswa dalam pembelajaran bangun ruang sisi datar dengan menggunakan kombinasi pendekatan pembelajaran kooperatif tipe jigsaw dan media benda asli. Penelitian ini menggunakan penelitian tindakan kelas karena sifat penelitian ini lebih sesuai dengan tugas pokok dan fungsi guru dalam meningkatkan kualitas hasil belajar siswa, langkah penelitian terdiri dari empat komponen utama yaitu perencanaan, observasi dan refleksi, adapun subyek penelitian adalah siswa kelas VIII-G SMP Negeri 2 Jatinangor yang berjumlah 40 siswa. data yang diperoleh pada penelitian ini adalah hasil belajar, hasil pengamatan kinerja guru. hasil observasi aktivitas belajar siswa dan respon siswa.Hasil penelitian menunjukan pembelajaran kooperatif tipe Jigsaw dapat meningkatkan kegiatan belajar siswa dari hasil observasi memperlihatkan bahwa terjadi peningkatan keaktifan siswa yang pada siklus ke-1 hanya rata-rata $58 \%$ menjadi $61 \%$ pada siklus ke 2 . Dari hasil observasi terjadi peningkatan aktivitas siswa dalam hal ini rata-rata untuk aspek partisipasi tidak mengalami peningkatan yaitu pada siklus ke-1 rata-rata $73 \%$ pada siklus 2 juga tetap $73 \%$. Namun untuk aspek penguasaan siswa terhadap materi pembelajaran bangun ruang sisi datar menunjukkan peningkatan. Hal ini dapat ditunjukkan dengan rata-rata hasil belajar pada siklus ke-1 rata-ratanya 53\% menjadi $79 \%$ pada siklus ke-2, aspek presentasi siswa setelah melakukan diskusi pada siklus 1 hanya $73 \%$ meningkat pada siklus 2 menjadi 78\%.Meningkatnya aktivitas siswa dalam proses belajar didukung oleh meningkatnya aktivitas guru dalam meningkatkan suasana pembelajaran yang mengarah pada pembelajaran kooperatif tipe Jigsaw.
\end{abstract}

Kata kunci: pembelajaran kooperatif tipe jigsaw

\begin{abstract}
The purpose of the study is to improve learning outcomes and student activities in learning to build a flat side space using a combination of cooperative learning approaches to the type of jigsaw and media of original objects. This study uses classroom action research because the nature of this study is more in line with the main tasks and functions of teachers in improving the quality of student learning outcomes, the research step consists of four main components, namely planning, observation and reflection, while the research subjects are VIII-G students of State Middle School 2 Jatinangor which numbered 40 students. The data obtained in this study are learning outcomes, observations of teacher performance. observation results of student learning activities and student responses. The results showed that Jigsaw type cooperative learning can improve student learning activities from observations showed that there was an increase in the activity of students who in the first cycle only average 58\% to $61 \%$ in the second
\end{abstract}


cycle. From the observation there was an increase in student activity in terms of this average for the participation aspect did not experience an increase, namely in the first cycle an average of $73 \%$ in cycle 2 also remained $73 \%$. However, for aspects of students' mastery of learning material, building a flat side space shows an increase. This can be indicated by the average learning outcomes in the first cycle of the average 53\% to $79 \%$ in the second cycle, aspects of student presentation after conducting discussions in cycle 1 only 73\% increased in cycle 2 to $78 \%$. Increasing student activity in the learning process is supported by increasing teacher activity in improving the learning atmosphere that leads to Jigsaw cooperative learning.

Keywords: jigsaw type cooperative learning

\section{PENDAHULUAN}

Pembelajaran matematika merupakan suatu bahan kajian yang memiliki objek abstrak dan dibangun melalui melalui proses penalaran deduktif, yaitu kebenaran suatu konsep diperoleh sebagai akibat logis dari kebenaran sebelumnya sehingga keterkaitan antar konsep dalam matematika bersifat sangat kuat dan jelas. Dalam pembelajaran matematika selama ini, dunia nyata hanya dijadikan tempat mengaplikasikan konsep. Siswa mengalami kesulitan belajar matematika di kelas. Akibatnya, siswa kurang menghayati atau memahami konsepkonsep matematika, sebagian besar siswa mengalami kesulitan untuk mengaplikasikan matematika dalam kehidupan sehari-hari. Selain itu, perlu menerapkan kembali konsep matematika yang telah dimiliki siswa pada kehidupan sehari-hari atau pada bidang lain sangat penting dilakukan.

Mata pelajaran matematika sejak dulu telah diajarkan di semua jenjang pendidikan, dalam pelajaran matematika tentu saja banyak rumus-rumus yang diajarkan. Rumus-rumus tersebut merupakan bagian yang tidak akan terpisahkan di dalam pelajaran matematika. Di setiap bab maupun subbab pasti ada rumus yang telah ditemukan. Rumus-rumus matematika yang begitu banyaknya membuat siswa jenuh dengan pelajaran matematika. Banyak siswa yang menganggap bahwa matematika itu pelajaran yang sulit. Dengan anggapan tersebut siswa merasa tidak mampu mempelajari mata pelajaran matematika dengan tuntas. Perasaan itulah yang membuat siswa tidak berusaha belajar maksimal atau belajar dengan kemampuan apa adanya yang dimiliki siswa.

Faktor-faktor yang mempengaruhi hasil belajar siswa pada mata pelajaran matematika salah satunya adalah metode mengajar yang sulit dimengerti oleh siswa. selain itu sarana dan prasarana pendukung juga ikut berpengaruh terhadap rendahnya hasil belajar siswa. Pembelajaran matematika yang terkesan membosankan juga merupakan faktor terbesar yang mengakibatkan siswa kurang mampu dalam memahami konsep untuk menyelesaikan soal matematika. Dengan pembelajaran yang membosankan membuat siswa kurang memperhatikan penjelasan dari guru sehingga siswa tidak mendapatkan hasil dari pembelajaran tersebut secara maksimal. Hasil pembelajaran siswa yang kurang maksimal tentu akan berpengaruh dalam cara berpikir siswa untuk menyelesaikan persoalan dalam pelajaran matematika, cara berpikir siswa yang sederhana membuat siswa cenderung pasif dan kurang serius dalam proses pembelajaran, sehingga materi yang disampaikan oleh guru tidak tertanam dalam benak siswa.

Penulis sebagai salah seorang guru matematika di SMP Negeri 2 Jatinangor Kabupaten Sumedang menemukan kenyataan bahwa motivasi belajar siswa yang rendah, siswa seringkali terlihat bosan, 
ini dapat dilihat dari siswa yang sudah tidak memperhatikan penjelasan guru, bermain sendiri, bahkan ada yang melamun, demikian juga dengan kemampuan menyelesaikan soal-soal yang diberikan, berdasarkan hasil tes siswa pada mata pelajaran matematika masih rendah, khususnya pada materi bangun ruang sisi datar didapati hasil bahwa siswa yang mendapatkan nilai di bawah 65 sebanyak 26 orang atau sebanyak $65 \%$, dapat dikategorikan belum tuntas, siswa yang mendapatkan nilai di atas atau sama dengan 65 hanya sebanyak 14 orang atau sekitar $35 \%$ yang tuntas. selain masalah hasil belajar yang masih rendah, terdapat pula kendala dalam proses pembelajaran, contohnya selama proses pembelajaran berlangsung hanya sedikit siswa yang berani bertanya kepada guru, hanya sedikit siswa yang berani mengajukan diri untuk mengerjakan soal ke depan kelas kecuali ditunjuk oleh guru, saat pembelajaran berlangsung banyak siswa yang tidak tahu beberapa istilah matematika atau pengetahuan prasyarat yang sebenarnya telah diajarkan pada pertemuan sebelumnya.

Untuk mengatasi kekurangankekurangan dalam kegiatan belajar matematika tersebut, maka penulis berencana untuk menerapkan model belajar yang berbeda, salah satu model tersebut adalah pembelajaran kooperatif (cooperative learning). Dengan pembelajaran kooperatif diharapkan akan dapat melatih siswa mendengarkan pendapat orang lain dan merangkum pendapat atau temuan-temuan dalam bentuk tulisan. Tugas-tugas kelompok akan dapat memacu siswa untuk bekerja sama, saling membantu satu sama lain dalam mengintegrasikan pengetahuanpengetahuan baru dengan pengetahuan yang telah dimilikinya. Selain itu pembelajaran kooperatif (cooperative learning) dalam matematika diharapkan dapat membantu siswa meningkatkan sikap positif. Siswa secara individu dapat membangun kepercayaan diri terhadap kemampuannya dalam memecahkan masalah-masalah matematika, sehingga akan mengurangi bahkan menghilangkan rasa cemas terhadap matematika (math anxiety) yang selama ini banyak dialami siswa. Pembelajaran kooperatif (cooperative learning) juga dapat membuat siswa menerima siswa lain yang berkemampuan dan berlatar belakang berbeda dengan menonjolkan interaksi dan kerjasama dalam sebuah kelompok belajar.

Darmawan \& Sastrawijaya (2017) mengungkapkan Model Pembelajaran Model diartikan sebagai kerangka konseptual yang digunakan sebagai pedoman dalam melakukan kegiatan, sedangkan model pembelajaran diartikan sebagai perencanaan yang berisi tentang rangkaian yang didesain untuk mencapai tujuan pendidikan tertentu Salah satu model pembelajaran kooperatif adalah tipe Jigsaw. Jigsaw merupakan model pembelajaran kooperatif dengan cara siswa belajar dalam kelompok kecil yang terdiri dari 4-6 orang secara heterogen dan bekerja sama saling ketergantungan yang positif dan bertanggung jawab atas ketuntasan bagian materi pelajaran yang harus dipelajari dan menyampaikan materi tersebut kepada anggota kelompok yang lain. model pembelajaran kooperatif tipe Jigsaw didesain untuk meningkatkan rasa tanggung jawab siswa terhadap pembelajarannya sendiri dan juga pembelajaran orang lain. Siswa tidak hanya mempelajari materi yang diberikan, tetapi mereka juga harus siap memberikan dan mengajarkan materi tersebut pada anggota kelompok yang lain. Dengan demikian "siswa saling tergantung satu dengan yang lain dan harus bekerja sama secara kooperatif untuk mempelajari materi yang ditugaskan". Para anggota dari kelompok yang berbeda dengan topik yang sama bertemu untuk diskusi (kelompok ahli) saling membantu satu 
sama lain tentang topik pembelajaran.yang ditugaskan kepada mereka. Kemudian siswasiswa itu kembali pada kelompok asal untuk menjelaskan kepada anggota kelompok yang lain tentang apa yang telah mereka pelajari sebelumnya pada pertemuan kelompok ahli. Yoshida (2017) Mode pembelajaran jigsaw memberikan pertimbangan tambahan yang memungkinkan siswa untuk mengakses sumber daya tertulis asli lainnya. Dalam sesi ini, siswa dapat mengakses sumber daya asli yang mereka minati atau menemukan sudut pandang yang sebelumya tidak diketahui.

Oleh karena itu setelah mengamati kelebihan dari metode belajar kooperatif type Jigsaw, maka penulis berencana melakukan suatu penelitian tindakan kelas dengan judul : "Upaya meningkatkan hasil belajar siswa pada materi bangun ruang sisi datar dengan menggunakan pembelajaran kooperatif tipe Jigsaw dan media benda asli“, tindakan kelas ini penulis lakukan di kelas VIII-G SMP Negeri 2 Jatinangor Kabupaten Sumedang.

Penulis mengidentifikasi kekurangan dalam kegiatan belajar sehingga timbulnya permasalahan sebagai berikut motivasi belajar siswa terhadap pelajaran matematika rendah, metode pembelajaran yang kurang menarik terutama dalam kegitan belajar dengan materi bangun ruang sisi datar. Konsep pembelajaran bangun ruang sisi datar terkesan abstrak, maka diperlukan media kongkret untuk membantu siswa memahami materi ajar. Berdasarkan identifikasi masalah di atas, maka rumusan masalah dalam penelitian ini adalah sebagai berikut bagaimana proses pembelajaran kooperatif tipe Jigsaw dan media benda asli dalam upaya meningkatkan hasil belajar siswa dalam materi bangun ruang sisi datar pada siswa kelas VIII-G SMP Negeri 2 Jatinangor Kabupaten Sumedang. Adapun tujuan dari penelitian ini adalah untuk mengetahui proses pembelajaran kooperatif tipe Jigsaw dan media benda asli dalam upaya meningkatkan hasil belajar siswa dalam materi bangun ruang sisi datar.

Manfaat penelitian yaitu bagi siswa adalah bermanfaat untuk meningkatkan keaktifan dalam proses pembelajaran karena suasana pembelajaran menyenangkan, motivasi belajar siswa meningkat, sehingga pada akhirnya akan meningkatkan hasil belajar siswa. Sementara bagi guru Hasil penelitian ini dapat dijadikan sebagai masukan untuk meningkatkan proses pembelajaran khususnya pada materi bangun ruang sisi datar dapat menambah inovasi dan kreativitas dalam kegiatan belajar mengajar dan bagi pihak sekolah hasil penelitian ini dapat dijadikan acuan dalam membuat kebijakan tentang peningkatan kualitas pembelajaran di sekolah, melalui pelatihan bagi guru tentang metode pengajaran dan media pembelajaran untuk meningkatkan kualitas pembelajaran. Hal ini sesuai dengan paparan Wakil Menteri Pendidikan dan kebudayaan Indonesia (2014) yang menyebutkan model pembelajaran sekolah yang baik adalah pembelajaran yang mendorong siswa untuk aktif dan inovatif. Di sisi lain, pembelajaran kooperatif merupakan komponen penting dari pembelajaran aktif yang menyusun siswa menjadi kelompok dengan peran yang ditentukan untuk setiap siswa dan tugas bersama untuk dicapai oleh kelompok. Karena itu, Teknik jigsaw telah sering digunakan dalam perencanaan pelajaran kontemporer.

Dalam kajian pustaka diketahui bahwa pembelajaran kooperatif adalah salah satu bentuk pembelajaran yang berdasarkan faham konstruktivis. Pembelajaran kooperatif merupakan strategi belajar dengan sejumlah siswa sebagai anggota kelompok kecil yang tingkat kemampuannya berbeda. Dalam menyelesaikan tugas kelompoknya, setiap siswa anggota kelompok harus saling bekerja sama dan saling membantu 
untuk memahami materi pelajaran. Dalam pembelajaran kooperatif, belajar dikatakan belum selesai jika salah satu teman dalam kelompok belum menguasai bahan pelajaran. Unsur-unsur dasar dalam pembelajaran kooperatif adalah sebagai berikut; para siswa harus memiliki tanggungjawab terhadap siswa lain dalam kelompoknya, selain tanggungjawab terhadap diri sendiri dalam mempelajari materi yang dihadapi, siswa harus berpandangan bahwa mereka semua memiliki tujuan yang sama, kemudian siswa membagi tugas dan berbagi tanggungjawab di antara para anggota kelompok (Mulyasa, 2005). Dan siswa diberikan satu evaluasi atau penghargaan yang akan ikut berpengaruh terhadap evaluasi kelompok. Menurut Djamarah (2002), pembelajaran kooperatif turut menambah unsur-unsur interaksi sosial pada pembelajaran sains. Di dalam pembelajaran kooperatif siswa belajar bersama dalam kelompok-kelompok kecil yang saling membantu satu sama lain. Kelas disusun dalam kelompok yang terdiri dari 4 atau 6 orang siswa, dengan kemampuan yang heterogen. Maksud kelompok heterogen adalah terdiri dari campuran kemampuan siswa, jenis kelamin, dan suku. Hal ini bermanfaat untuk melatih siswa menerima perbedaan dan bekerja dengan teman yang berbeda latar belakangnya. Pada pembelajaran kooperatif diajarkan keterampilan-keterampilan khusus agar dapat bekerja sama dengan baik di dalam kelompoknya, seperti menjadi pendengar yang baik, siswa diberi lembar kegiatan yang berisi pertanyaan atau tugas yang direncanakan untuk diajarkan. Selama kerja kelompok, tugas anggota kelompok adalah mencapai ketuntasan.

Tujuan pembelajaran kooperatif berbeda dengan kelompok tradisional yang menerapkan sistem kompetisi, di mana keberhasilan individu diorientasikan pada kegagalan orang lain. Sedangkan tujuan dari pembelajaran kooperatif adalah menciptakan situasi di mana keberhasilan individu ditentukan atau dipengaruhi oleh keberhasilan kelompoknya Model pembelajaran kooperatif dikembangkan untuk mencapai setidak-tidaknya tiga tujuan pembelajaran penting yang dirangkum oleh Djamarah (2002), yaitu (a) Hasil belajar akademik (b) Penerimaan terhadap perbedaan individu dan (c) Pengembangan keterampilan sosial. Dalam pembelajaran kooperatif tidak hanya mempelajari materi saja, tetapi siswa juga harus mempelajari keterampilan-keterampilan khusus yang disebut keterampilan kooperatif.

Pembelajaran kooperatif ini berfungsi untuk melancarkan hubungan kerja dan tugas. Peranan hubungan kerja dapat dibangun dengan membangun tugas anggota kelompok selama kegiatan. Terdapat enam fase utama dalam pembelajaran kooperatif menurut Djamarah (2002) pembelajaran kooperatif dimulai dengan guru menginformasikan tujuan dari pembelajaran dan memotivasi siswa untuk belajar. Fase ini diikuti dengan penyajian informasi, sering dalam bentuk teks bukan verbal. Kemudian dilanjutkan langkah-langkah di mana siswa di bawah bimbingan guru bekerja bersama-sama untuk menyelesaikan tugas-tugas yang saling bergantung. Fase terakhir dari pembelajaran kooperatif meliputi penyajian produk akhir kelompok atau mengetes apa yang telah dipelajari oleh siswa dan pengenalan kelompok dan usaha-usaha individu.

Adapun pengertian pembelajaran kooperatif tipe Jigsaw adalah suatu tipe pembelajaran kooperatif yang terdiri dari beberapa anggota dalam satu kelompok yang bertanggung jawab atas penguasaan bagian materi belajar dan mampu mengajarkan bagian tersebut kepada anggota lain dalam kelompoknya (Lie, 2008). Menurut Yoshida 
(2018) Teknik “jigsaw” adalah strategi pembelajaran kooperatif berdasarkan dinamika kelompok dan interaksi sosial. Substansi dari teknik pembelajaran ini adalah yang paling dipelajari dan paling sering digunakan dari pendekatan pembelajaran kooperatif hingga saat ini. Model pembelajaran kooperatif tipe Jigsaw merupakan model pembelajaran kooperatif, dengan siswa belajar dalam kelompok kecil yang terdiri dari 4-6 orang secara heterogen dan bekerja sama saling ketergantungan yang positif dan bertanggung jawab atas ketuntasan bagian materi pelajaran yang harus dipelajari dan menyampaikan materi tersebut kepada anggota kelompok yang lain.

Jigsaw didesain untuk meningkatkan rasa tanggung jawab siswa terhadap pembelajarannya sendiri dan juga pembelajaran orang lain. Siswa tidak hanya mempelajari materi yang diberikan, tetapi mereka juga harus siap memberikan dan mengajarkan materi tersebut pada anggota kelompoknya yang lain. Dengan demikian, "siswa saling tergantung satu dengan yang lain dan harus bekerja sama secara kooperatif untuk mempelajari materi yang ditugaskan. Para anggota daritim-timyang berbedadengan topik yang sama bertemu untuk diskusi (tim ahli) saling membantu satu sama lain tentang topik pembelajaran yang ditugaskan kepada mereka. Kemudian siswa-siswa itu kembali pada tim/kelompok asal untuk menjelaskan kepada anggota kelompok yang lain tentang apa yang telah mereka pelajari sebelumnya pada pertemuan tim ahli. Selain itu, bekerja sama antar kelompok ataupun sesama siswa mempunyai banyak kesempatan untuk mengolah informasi dan meningkatkan ketrampilan berkomunikasi. Type mengajar jigsaw dikembangkan oleh Aronson sebagai metode belajar cooperatif learning. Type ini dapat digunakan dalam pengajaran membaca, menulis, mendengarkan, ataupun berbicara.
Pada model pembelajaran kooperatif tipe Jigsaw, menurut Widiastini, dkk (2014) terdapat kelompok asal dan kelompok ahli. Kelompok asal, yaitu kelompok induk siswa yang beranggotakan siswa dengan kemampuan, asal, dan latar belakang keluarga yang beragam. Kelompok asal merupakan gabungan dari beberapa ahli. Kelompok ahli, yaitu kelompok siswa yang terdiri dari anggota kelompok asal yang berbeda yangditugaskan untuk mempelajari dan mendalami topik tertentu dan menyelesaikan tugas-tugas yang berhubungan dengan topiknya untuk kemudian dijelaskan kepada anggota kelompok asal. Hubungan antara kelompok asal dan kelompok ahli, para anggota dari kelompok asal yang berbeda, bertemu dengan topik yang sama dalam kelompok ahli untuk berdiskusi dan membahas materi yang ditugaskan pada masing-masing anggota kelompok serta membantu satu sama lain untuk mempelajari topik mereka tersebut. Setelah pembahasan selesai, para anggota kelompok kemudian kembali pada kelompok asal dan mengajarkan pada teman sekelompoknya apa yang telah mereka dapatkan pada saat pertemuan di kelompok ahli.

Menurut Trisdiono \& Zuwanti (2017) Jigsaw didesain selain untuk meningkatkan rasa tanggung jawab, siswa secara mandiri juga dituntut saling ketergantungan yang positif (saling memberi tahu) terhadap teman sekelompoknya. Menurut Yoshida (2017) Pengelompokan kegiatan dari masingmasing siswa dapat mengembangkan aturan yang kompleks dan kecerdasan yang lebih tinggi, di mana pengaturan diri dari atas ke bawah muncul dan penampilan keseluruhan grup terlihat seperti satu objek. Selanjutnya di akhir pembelajaran, siswa diberi kuis secara individu yang mencakup topik materi yang telah dibahas. Kunci tipe Jigsaw ini adalah interdependensi setiap siswa 
terhadap anggota tim yang memberikan informasi yang diperlukan dengan tujuan agar dapat mengerjakan kuis dengan baik. Untuk pelaksanaan pembelajaran kooperatif tipe Jigsaw, disusun langkah-langkah pokok sebagai berikut; (1) pembagian tugas, (2) pemberian lembar ahli, (3) mengadakan diskusi, (4) mengadakan kuis.

Dalam suatu proses belajar mengajar, dua unsur yang amat penting adalah media mengajar dan metode pengajaran. Kedua aspek ini sangat berkaitan. Pemilihan salah satu media mengajar tentu akan mempengaruhi jenis media pembelajaran yang sesuai, meskipun masih ada berbagai aspek lain yang harus diperhatikan dalam memilih media, antara lain tujuan pembelajaran, jenis tugas dan respon yang diharapkan dikuasai siswa setelah pembelajaran yang berlangsung dan kontak pembelajaran, termasuk karakteristik siswa. Meskipun demikian, dapat dikatakan bahwa salah satu fungsi utama media pembelajaran adalah sebagai alat bantu mengajar yang turut mempengaruhi iklim, kondisi dan lingkungan belajar yang ditata dan diciptakan oleh guru.

Pembelajaran yang efektif memerlukan perencanaan yang baik seperti yang dikemukakan oleh Hamalik (2008) Media yang akan digunakan dalam proses pembelajaran juga memerlukan perencanaan yang baik. Meskipun demikian, kenyataan di lapangan menunjukkan bahwa seorang guru memilih salah satu media dalam kegiatannya di kelas, seringkali didasarkan atas pertimbangan, antara lain: (1) merasa akrab dengan media tersebut, (2) ingin memberi gambaran atau penjelasan yang lebih konkrit.

Bermacam-macam benda asli dapat digunakan oleh guru untuk menyampaikan pesan ajaran kepada siswa melalui penglihatan dan pendengaran untuk menghindari verbalisme yang masih mungkin terjadi kalau hanya digunakan alat bantu visual semata. Maka dari itulah guru-guru mulai merumuskan tujuan pembelajaran berdasarkan tingkah laku siswa.
Untuk mencapai tujuan pembelajaran tersebut, mulai dipakai berbagai format media. Dan dari pengalaman mereka, guru mulai belajar melalui media visual, sebagian melalui media audio, sebagian lagi senang melalui media cetak yang lain melalui media audio visual, dan sebagainya.

Berbagai jenis media benda asli yang dapat digunakan dalam proses komunikasi pembelajaran menurut Sudjana \& Rivai (2005) digolongkan menjadi: (1) Media visual meliputi gambar/tato, sketsa, diagram, charts, grafik, kartun, poster, peta dan globe, (2) Media dengar meliputi radio, magnetic, tape recorder, magnetic sheet recorder, laboratorium bahasa, (3) Projected still media meliputi slide, film strip, over head projector, opaque projector, techitoscope, micro projector, micro film, (4) Projected motion media meliputi film, film loop, televisi, closed circuit television (CCTV), video tape recorder, komputer.

Penggunaan media benda asli dalam pembelajaran memegang peranan penting sebagai alat bantu untuk menciptakan kegiatan pembelajaran yang efektif, karena dapat mendorong motivasi dan meningkatkan hasil prestasi belajar siswa. Luta (2016) menjelaskan Setiap proses pembelajaran dilandasi dengan adanya beberapa unsur antara lain tujuan, bahan, metode, media, alat, serta evaluasi. Dalam pencapaian tujuan, peranan media pembelajaran merupakan bagian terpenting pembelajaran yang dapat membantu siswa lebih mudah untuk memahami materi. Dalam proses belajar mengajar media benda asli atau nyata dipergunakan dengan tujuan membantu guru agar proses belajar siswa lebih efektif dan efisien.

Berdasarkan hal tersebut, dalam pembelajaran matematika media benda asli atau benda nyata sebenarnya sangat diharapkan dapat membantu mengatasi kesulitan dalam memahami materi dalam proses belajar mengajar. Jika dalam pembelajaran matematika tidak dapat menyajikan benda nyata, guru dapat 
menyajikan menggunakan media tiruan benda nyata. Contoh penyajian dengan menggunakan benda nyata dalam materi bangun ruang maka kita bisa mempergunakan kardus kue dan pembungkus pasta gigi untuk membuktikan bangun balok secara langsung. Karena metode ini dapat memberikan motivasi siswa dan memperjelas penyampaian materi sehingga siswa dengan mudah memahami materi balok yang disampaikan dalam pembelajaran. Penggunaan topi pesta juga membantu siswa dalam memahami kerucut.

Pengertian bangun ruang sisi datar Bangun ruang sisi datar adalah bangun tiga dimensi yang semua sisinya datar, yaitu bangun yang dapat dilihat dari semua sisinya datar. Media pembelajaran berupa model bangun ruang sisi datar dapat dijadikan media pengajaran. Benda asli sangat membantu guru dalam menerangkan sesuatu kepada siswa untuk memahami materi yang disampaikan. Model bangun ruang sisi datar adalah media yang dibuat dengan ukuran tiga dimensi sehingga menyerupai benda aslinya untuk menjelaskan hal-hal yang tak mungkin kita peroleh dari benda yang sebenarnya. Model bangun ruang sisi datar dapat dibuat dalam ukuran lebih besar atau lebih kecil dari benda aslinya, atau memperlihatkan bagian-bagian yang rumit dari sebuah benda yang sebenarnya keadaan tertutup.Dalam penelitian tindakan kelas ini, bangun ruang sisi datar yang akan dibahas adalah diantaranya adalah kubus, balok, limas dan prisma.

\section{METODE PENELITIAN}

Penelitian ini menggunakan penelitian tindakan kelas (classroom action research), karena penelitian tindakan kelas merupakan penelitian yang lebih sesuai dengan tugas pokok dan fungsi guru, yaitu meningkatkan kualitas pembelajaran, meningkatkan kualitas hasil belajar siswa, serta mencapai tujuan pembelajaran. adapun komponen tindakannya adalah terdiri dari perencanaan (planning), tindakan (acting), pengamatan (observing), dan refleksi (reflecting). Penelitian Tindakan Kelas merupakan bentuk kajian yang bersifat reflektif oleh pelaku tindakan, dilakukan untuk meningkatkan kematangan rasional dari tindakan-tindakan dalam melakukan tugas, memperdalam pemahaman terhadap tindakantindakan yang dilakukan itu, serta memperbaiki kondisi tempat praktik pembelajaran tersebut dilakukan (Arikunto, 2005).

Dalam penelitian ini yang menjadi subyek penelitian adalah siswa kelas VIII-G SMP Negeri 2 Jatinangor, Jumlah siswa kelas VIII-G seluruhnya ada 40 siswa, terdiri dari 21 siswa laki-laki dan 19 siswa perempuan. Penelitian ini dilaksanakan pada mata pelajaran matematika dengan materi bangun ruang sisi datar.

Teknik pengumpulan data dalam penelitian tindakan kelas ini adalah (a) Data hasil belajar, (b) Data hasil observasi/ pengamatan kinerja guru dan (c) Data hasil observasi/pengamatan keaktifan siswa. Sedangkan cara pengambilan data berasal dari hasil belajar diambil dengan memberikan tes kepada siswa, data tentang kinerja guru dalam proses pembelajaran pada saat dilaksanakannya tindakan dengan menggunakan lembar observasi dan data tentang aktifitas siswa dengan menggunakan lembar observasi.

Teknik analisis data dilakukan dengan menggunakan kriteria dari hasil Kemampuan siswa untuk menganalisa kemampuan siswa, dibuat instrumen lembar soal yang terdiri dari beberapa soal dengan pedoman apabila rata rata hasil belajar $\leq 75 \%$. Data yang diperoleh dari hasil belajar siswa ditentukan rata rata hasil belajar dengan perhitungan sebagai berikut: Mean $(x)=\sum x / n$ Untuk mencari nilai rata rata dengan cara menjumlahkan semua skor kemudian dibagi dengan banyaknya siswa yang memiliki skor tersebut Kriteria rata rata hasil belajar adalah : $80-100$ baik sekali, $66-79$ baik, 56-65 
cukup, 40-55 kurang dan 30-39 gagal. Untuk melihat ketuntasan Individu nilai yang diperoleh siswa harus $\geq 75 \%$ dari hasildata yang diperoleh setelah melihat hasil belajar siswa maka dapat ditentukan ketuntasan belajar individu, menggunakan analisis deskriptif selanjutnya siswa dikatakan tuntas individu jika nilai hasil belajar $\geq 70$.

Indikator ketercapaian penelitian untuk mengetahui keberhasilan penelitian. adalah 1) Rata rata nilai hasil belajar siswa $\geq 70$ 2) Ketuntasan klasikal $85 \%$ siswa mencapai nilai $\geq 703$ ) Kinerja guru memperolehprosentase $\geq 80 \%$ dan 4) Proses pelaksanaan pembelajaran dikatakan berhasil jika ada peningkatan jumlah siswa yang aktif setiap siklusnya, $\geq 75 \%$ siklus dihentikan jika dalam proses pelaksanaan pembelajaran sudah mencapai kreteria baik $75 \%$ dari seluruh siswa

\section{HASIL DAN PEMBAHASAN}

Kegiatan penelitian tindakan kelas diawali dari kegiatan siklus 1 dan siklus 2, dengan maksud untuk mengetahui peningkatan pembelajaran siswa pada setiap tahapan siklus, selain data proses juga diamati mengenai minat siswa yaitu data tentang tanggapan siswa atau kepuasan siswa mengikuti kegiatan pembelajaran, Sedangkan data keberhasilan hasil yang diamati pada penelitian tindakan kelas ini meliputi data hasil belajar bangun ruang sisi datar siswa.

Pengamatan terhadap data proses pembelajaran dilakukan sesuai dengan indikator keberhasilan proses yang telah ditetapkan dalam perencanaan awal. Selanjutnya data yang muncul dalam pelaksanaan tindakan kemudian diamati dan dipaparkan. Data proses yang diamati pada penelitian tindakan kelas ini meliputi : (1) Data mengenai ketepatan prosedur pelaksanaan tindakan yang dilakukan guru atau peneliti, (2) Data mengenai keaktifan siswa, (3) Data perhatian siswa, (4) Data partisipasi siswa, dan (5) Data presentasi siswa.

\subsection{Hasil}

\section{Siklus 1}

Kegiatan siklus 1 terdiri dari empat tahap, yakni perencanaan, pelaksanaan, observasi, dan refleksi, berdasarkan hasil observasi dalam siklu I untuk aspek keaktifan siswa pada tabel 1, aspek yang diukur adalah aktivitas bertanya, aktivitas memberikan tanggapan, dan aktivitas memberikan penjelasan kepada anggota atau teman lain dalam kelompok ahli atau dalam kelompok asal. perolehan rata-rata skor aspek keaktifan siswa adalah 58\%. Hal ini aspek keaktifan siswa pada tabel 1 masih tergolong rendah, sedangkan aspek keaktifan siswa dikatakan berhasil jika mencapai lebih dari atau sama dengan $70 \%$, sementara untuk aspek perhatian siswa dalam mengikuti kegiatan belajar mengajar adalah 76\%. Hal ini tergolong baik, artinya siswa sudah mulai tertarik dalam kegiatan belajar mengajar yang menggunakan kombinasi pendekatan pembelajaran kooperatif tipe jigsaw dan media benda asli. pada siklus 1 perolehan skor rata-rata kelompok aspek partisipasi siswa dalammengikuti kegiatan belajar mengajar tergolong cukup, artinya keikutsertaan siswa dalam diskusi kelompok, keikutsertaan siswa dalam mengeluarkan pendapat dalam diskusi kelompok, keikutsertaan siswa menjadi pembicara saat mewakili presentasi kelompok dan keikutsertaan siswa dalam merumuskan hasil diskusi kelompok sudah mulai nampak, meskipun baru tergolong cukup, namun untuk skor rata-rata kelompok aspek presentasi siswa dalam mengikuti kegiatan belajar adalah 58\%. Hal ini aspek presentasi siswa dalam mengikuti kegiatan belajar mengajar tergolong kurang, artinya keberanian siswa dalam menjelaskan hasil diskusi di depan kelas mewakili kelompoknya harus ditingkatkan lagi untuk mengetahui hasil evaluasi pada Siklus pertama, dalam aspek penguasaan siswa terhadap materi pembelajaran dapat dilihat pada tabel 1 dan grafik 1 berikut : 
Tabel.1.Perolehan skor rata-rata kelompok pada aspek keaktifan siswa pada Siklus 1

\begin{tabular}{ccccc}
\hline Kelompok & $\begin{array}{c}\text { Skor } \\
\text { Perolehan }\end{array}$ & $\begin{array}{c}\text { Skor } \\
\text { ideal }\end{array}$ & $\%$ & Keterangan \\
\hline I & 44 & 70 & $58 \%$ & \\
\hline II & 44 & 70 & $58 \%$ & \\
\hline III & 44 & 70 & $58 \%$ & \\
\hline IV & 45 & 70 & $60 \%$ & Tertinggi \\
\hline V & 44 & 70 & $58 \%$ & \\
\hline VI & 43 & 70 & $57 \%$ & \\
\hline VII & 45 & 70 & $60 \%$ & Tertinggi \\
\hline VIII & 44 & 70 & $58 \%$ & \\
\hline Rata-rata & 44 & 70 & $58 \%$ & \\
\hline
\end{tabular}

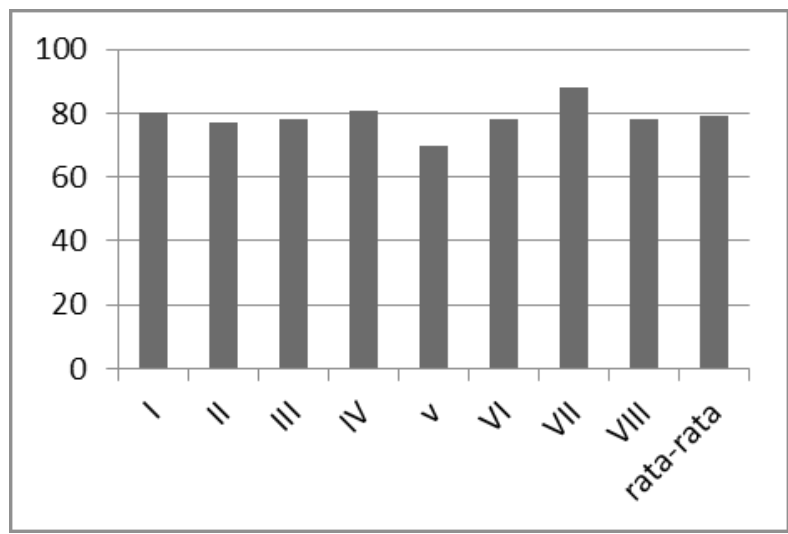

Grafik.1 Prosentase skor rata-rata kelompok pada aspek perhatian/minat belajar siswa Siklus 1

Dalam aspek keaktifan siswa, aspek yang diukur adalah aktivitas bertanya, aktivitas memberikan tanggapan, dan aktivitas memberikan penjelasan kepada anggota atau teman lain dalam kelompok ahli atau dalam kelompok asal. Hasil observasi pada siklus 1 perolehan rata-rata skor tabel 1 aspek keaktifan siswa adalah 58\%. Hal ini aspek keaktifan siswa masih tergolong rendah, sedangkan aspek keaktifan siswa dikatakan berhasil jika mencapai lebih dari atau sama dengan $70 \%$. Adaapun hasil observasi pada siklus 1 perolehan skor rata-rata kelompok aspek partisipasi siswa dalam mengikuti kegiatan belajar mengajar adalah $73 \%$ pada tabel 2 . Hal ini aspek partisipasi siswa dalam mengikuti kegiatan belajar mengajar tergolong cukup seperti pada tabel 2.

Tabel. 2 Perolehan persentase skor rata-rata kelompok pada aspek partisipasi siswa kegiatan belajar pada siklus 1

\begin{tabular}{ccccc}
\hline Kelompok & $\begin{array}{c}\text { Skor } \\
\text { Perolehan }\end{array}$ & $\begin{array}{c}\text { Skor } \\
\text { ideal }\end{array}$ & $\%$ & Keterangan \\
\hline I & 55 & 80 & 69 & \\
\hline II & 55 & 80 & 69 & \\
\hline III & 54 & 80 & 68 & Terendah \\
\hline IV & 54 & 80 & 68 & Terendah \\
\hline V & 61 & 80 & 76 & \\
\hline VI & 64 & 80 & 80 & \\
\hline VII & 66 & 80 & 83 & Tertinggi \\
\hline VIII & 56 & 80 & 70 & \\
\hline Rata-rata & 58 & 80 & 73 & \\
\hline
\end{tabular}


Keikutsertaan siswa dalam diskusi mewakili presentasi kelompok dan keikutsertaan kelompok, keikutsertaan siswa dalam siswa dalam merumuskan hasil diskusi kelompok mengeluarkan pendapat dalam diskusi kelompok, keikutsertaan siswa menjadi pembicara saat sudah mulai nampak, meskipun baru tergolong cukup seperti pada grafik 2 berikut :

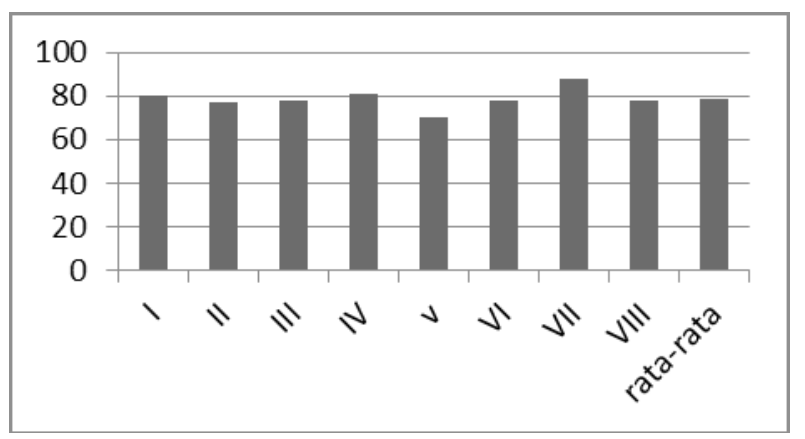

Grafik 2 Perolehan prosentase skor rata-rata kelompok pada aspek partisipasi siswa dalam kegiatan belajar Siklus 1

Hasil observasi pada aspek presentasi siswa pada siklus 1 perolehan skor ratarata kelompok aspek presentasi siswa dalam mengikuti kegiatan belajar mengajar adalah $58 \%$ pada tabel 3 . Hal ini aspek presentasi siswa dalam mengikuti kegiatan belajar mengajar tergolong kurang, artinya keberanian siswa dalam menjelaskan hasil diskusi di depan kelas mewakili kelompoknya harus ditingkatkan lagi.

Tabel. 3. Perolehan prosentase skor rata-rata kelompok pada aspek presentasi siswa kegiatan belajar pada siklus 1

\begin{tabular}{ccccc}
\hline Kelompok & $\begin{array}{c}\text { Skor } \\
\text { Perolehan }\end{array}$ & $\begin{array}{c}\text { Skor } \\
\text { ideal }\end{array}$ & $\%$ & Keterangan \\
\hline I & 14 & 25 & $56 \%$ & Terendah \\
\hline II & 15 & 25 & $60 \%$ & Tertinggi \\
\hline III & 14 & 25 & $56 \%$ & Terendah \\
\hline IV & 15 & 25 & $60 \%$ & Tertinggi \\
\hline V & 15 & 25 & $60 \%$ & Tertinggi \\
\hline VI & 15 & 25 & $60 \%$ & Tertinggi \\
\hline VII & 15 & 25 & $60 \%$ & Tertinggi \\
\hline VIII & 14 & 25 & $56 \%$ & Terendah \\
\hline Rata-rata & 14 & 25 & $58 \%$ & \\
\hline
\end{tabular}

Pada tabel 4 dan grafik 3 merupakan aspek penguasaan siswa terhadap materi hasil Evaluasi pada siklus pertama, dalam pembelajaran.

Tabel 4.Perolehan rata-rata kelompok hasil belajar bangun ruang sisi datar siswa siklus 1

\begin{tabular}{ccccc}
\hline Kelompok & $\begin{array}{c}\text { Skor } \\
\text { Perolehan }\end{array}$ & $\begin{array}{c}\text { Skor } \\
\text { ideal }\end{array}$ & $\%$ & Keterangan \\
\hline I & 52 & 100 & $56 \%$ & \\
\hline II & 47 & 100 & $47 \%$ & \\
\hline III & 49 & 100 & $49 \%$ & \\
\hline IV & 46 & 100 & $46 \%$ & Terendah \\
\hline V & 54 & 100 & $54 \%$ & \\
\hline VI & 61 & 100 & $61 \%$ & \\
\hline VII & 69 & 100 & $69 \%$ & Tertinggi \\
\hline VIII & 47 & 100 & $47 \%$ & \\
\hline Rata-rata & 53 & 100 & $53 \%$ & \\
\hline
\end{tabular}




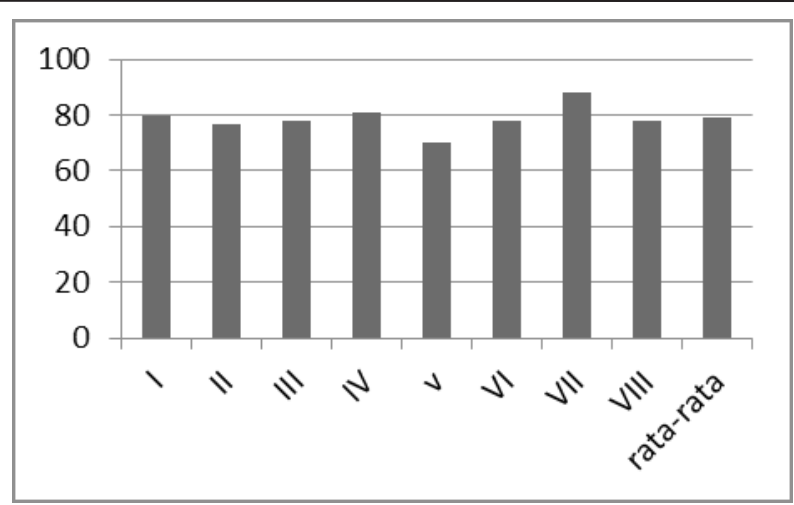

Grafik 3 Perolehan rata-rata kelompok hasil belajar bangun ruang sisi datar siswa siklus 1

Dari hasil refleksi pada siklus 1 diketahui masih terdapat beberapa kekurangan dalam kegiatan pembelajaran dengan metode jigsaw diantaranya yaitu sebagian siswa belum terbiasa dengan kondisi belajar dengan menggunakan kombinasi pendekatan pembelajaran kooperatif tipe Jigsaw dan media benda asli. Mereka belummerasa senang dan antusias dalam belajar. Hal ini bisa dilihat dari hasil observasi ratarata prosentase data proses terhadap aspek ketepatan prosedur pelaksanaan tindakan yang dilakukan guru atau peneliti, keaktifan, perhatian, partisipasi, dan presentasi siswa, dalam proses belajar mengajar hanya mencapai $69 \%$. Selain itu hasil belajar bangun ruang sisi datar siswa pada siklus pertama masih kurang, baru mencapai rata-rata 53\% pada tabel 4 dan siswa yang mencapai ketuntasan belajar hanya mencapai $43 \%$.

Untuk memperbaiki kelemahan dan mempertahankan keberhasilan yang telah dicapai pada siklus pertama, maka pelaksanaan pada siklus kedua

Siklus 2

Hasil observasi aktivitas siswa dalam proses belajar mengajar yang meliputi aspek minat, perhatian, partisipasi, dan presentasi selama siklus 2 dapat dilihat pada tabel 5 berikut ini.

Tabel 5 Perolehan persentase skor rata-rata kelompok pada aspek keaktifan siswa pada siklus ke 2

\begin{tabular}{ccccc}
\hline Kelompok & $\begin{array}{c}\text { Skor } \\
\text { Perolehan }\end{array}$ & $\begin{array}{c}\text { Skor } \\
\text { ideal }\end{array}$ & $\%$ & Keterangan \\
\hline I & 54 & 75 & $72 \%$ & tertinggi \\
\hline II & 50 & 75 & $66 \%$ & \\
\hline III & 50 & 75 & $66 \%$ & \\
\hline IV & 50 & 75 & $66 \%$ & \\
\hline V & 50 & 75 & $66 \%$ & \\
\hline VI & 53 & 75 & $70 \%$ & \\
\hline VII & 54 & 75 & $72 \%$ & tertinggi \\
\hline VIII & 51 & 75 & $68 \%$ & \\
\hline Rata-rata & 51 & 75 & $68 \%$ & \\
\hline
\end{tabular}

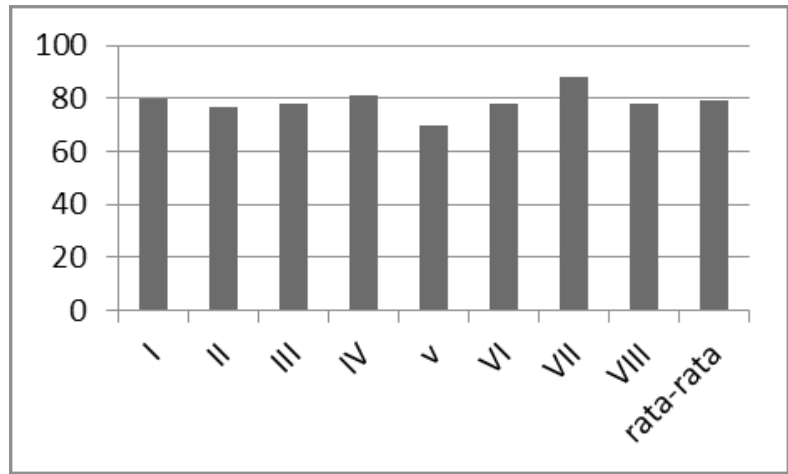

Grafik 4 Perolehan persentase skor rata-rata kelompok pada aspek keaktifan siswa pada siklus ke 2 
Hasil observasi aspek keaktifan siswa pada grafik 4 melalui siklus kedua mencapai $68 \%$ pada tabel 5, hal initergolong cukup.Adapeningkatan sebesar $3 \%$, yaitu dari $58 \%$ pada siklus pertama menjadi $68 \%$ pada tabel 5 siklus kedua. Pada siklus kedua ada peningkatan aktivitas bertanya, aktivitas memberikan tanggapan, dan aktivitas memberikan penjelasan kepada anggota atau teman lain dalam kelompok ahli atau dalam kelompok asal. Aspek keaktifan siswa pada siklus kedua sebesar $72 \%$ sudah mencapai target minimal yang ditetapkan pada indikator keberhasilan proses $70 \%$.

Dari hasil observasi terhadap aspek minat dan Perhatian siswa terhadap kegiatan belajar sebagai tabel 6 berikut :

Tabel 6 Perolehan skor rata-rata kelompok aspek minat, terhadap kegiatan belajar pada siklus 2

\begin{tabular}{ccccc}
\hline Kelompok & $\begin{array}{c}\text { Skor } \\
\text { Perolehan }\end{array}$ & $\begin{array}{c}\text { Skor } \\
\text { ideal }\end{array}$ & $\%$ & Keterangan \\
\hline I & 42 & 50 & 84 & \\
\hline II & 42 & 50 & 84 & \\
\hline III & 41 & 50 & 82 & terendah \\
\hline IV & 41 & 50 & 82 & terendah \\
\hline V & 42 & 50 & 84 & \\
\hline VI & 45 & 50 & 90 & \\
\hline VII & 46 & 50 & 92 & tertinggi \\
\hline VIII & 41 & 50 & 82 & terendah \\
\hline Rata-rata & 42,2 & 50 & 85 & \\
\hline
\end{tabular}

Hasil observasi aspek perhatian siswa grafik 5 pada siklus kedua mencapai rata-rata $85 \%$, hal ini tergolong baik. Ada peningkatan sebesar $9 \%$, yaitu dari $76 \%$ pada siklus pertama menjadi $85 \%$ pada tabel 6 siklus kedua. Pada siklus kedua ada peningkatan perhatian karena pembelajaran ditunjang dengan adanya power poin yang menarik. Aspek keaktifan siswa pada siklus kedua sebesar $85 \%$ pada tabel 6 sudah mencapai target minimal yang ditetapkan pada indikator keberhasilan proses sebesar $65 \%$.

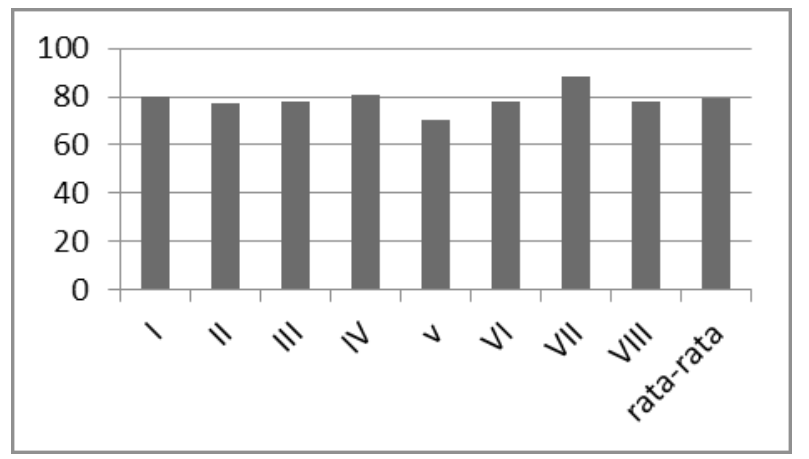

Grafik 5. Perolehan skor rata-rata kelompok aspek minat, terhadap kegiatan belajar pada siklus 2

Adapun hasil evaluasi pada siklus materi pembelajaran dapat dilihat pada tabel 7 kedua, dalam aspek penguasaan siswa terhadap berikut ini :

Tabel.7 Perolehan rata-rata kelompok hasil belajar bangun ruang sisi datar pada siklus 2

\begin{tabular}{ccccc}
\hline Kelompok & $\begin{array}{c}\text { Skor } \\
\text { Perolehan }\end{array}$ & $\begin{array}{c}\text { Skor } \\
\text { ideal }\end{array}$ & $\%$ & Keterangan \\
\hline I & 80 & 100 & $80 \%$ & \\
\hline II & 77 & 100 & $77 \%$ & \\
\hline III & 78 & 100 & $78 \%$ & \\
\hline IV & 81 & 100 & $81 \%$ & \\
\hline V & 70 & 100 & $70 \%$ & terendah \\
\hline VI & 78 & 100 & $78 \%$ & \\
\hline VII & 88 & 100 & $88 \%$ & tertinggi \\
\hline VIII & 78 & 100 & $78 \%$ & \\
\hline Rata-rata & 79 & 100 & $79 \%$ & \\
\hline
\end{tabular}




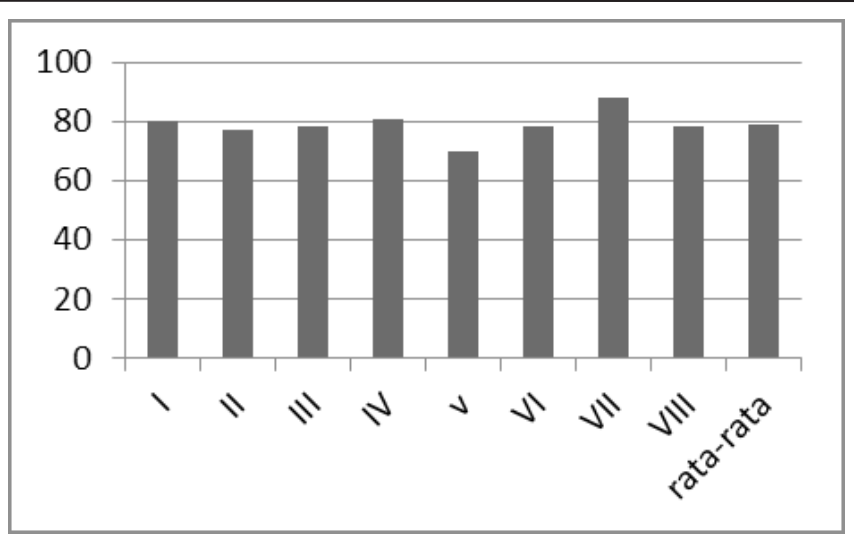

Grafik 6. Perolehan rata-rata kelompok hasil belajarbangun ruang disi datar siswa pada Siklus 2

Pada grafik 6 menjelaskan aspek ketepatan prosedur pelaksanaan tindakan yang dilakukan guru atau peneliti dalam proses belajar mengajar, penguasaan siswa terhadap materi pembelajaran meningkat 26\%. Dari skor ideal 100 skor perolehan rata-rata pada tabel 7 siklus kedua mencapai 79 atau $79 \%$ dan siswa yang mencapai ketuntasan belajar meningkat sekitar $44 \%$, dari hanya $43 \%$ pada siklus1 menjadi $87 \%$ pada siklus 2 . Hal ini dapat dilihat pada tabel atau grafik diatas.

\subsection{Pembahasan}

Faktor-faktor yang mempengaruhi hasil belajar siswa pada mata pelajaran matematika salah satunya adalah metode mengajar yang sulit dimengerti oleh siswa. selain itu sarana dan prasarana pendukung juga ikut berpengaruh terhadap rendahnya hasil belajar siswa. membuat siswa kurang memperhatikan penjelasan dari guru sehingga siswa tidak mendapatkan hasil dari pembelajaran tersebut secara maksimal. Hasil pembelajaran siswa yang kurang maksimal tentu akan berpengaruh dalam cara berpikir siswa untuk menyelesaikan persoalan dalam pelajaran matematika.

Motivasi belajar siswa yang rendah, siswa seringkali terlihat bosan, ini dapat dilihat dari siswa yang sudah tidak memperhatikan penjelasan guru, bermain sendiri, bahkan ada yang melamun, demikian juga dengan kemampuan menyelesaikan soal-soal yang diberikan, berdasarkan hasil tes siswa pada mata pelajaran matematika masih rendah, khususnya pada materi bangun ruang sisi datar didapati hasil bahwa siswa yang mendapatkan nilai di bawah 65 sebanyak 26 orang atau sebanyak 65\%, dapat dikategorikan belum tuntas, siswa yang mendapatkan nilai di atas atau sama dengan 65 hanya sebanyak 14 orang atau sekitar 35\% yang tuntas.

Dari hasil observasi memperlihatkan bahwa terjadi peningkatan keaktifan siswa yang pada siklus ke-1 rata-rata $58 \%$ menjadi $61 \%$ pada siklus ke 2 . Dari hasil observasi memperlihatkan bahwa juga terjadi peningkatan aktivitas siswa dalam hal ini rata-rata untuk aspek partisipasi tidak mengalami peningkatan yaitu pada siklus ke-1 rata-rata $73 \%$ pada siklus 2 juga tetap 73\%. Namun untuk aspek penguasaan siswa terhadap materi pembelajaran dalam hal ini bangun ruang sisi datar menunjukkan peningkatan. Hal ini dapat ditunjukkan dengan rata-rata hasil belajar pada siklus ke-1 rata-ratanya 53 atau 53\% menjadi 80 atau $80 \%$ pada siklus ke-2, kemudian aspek presentasi siswa setelah melakukan diskusi pada siklus 1 hanya $73 \%$ meningkat pada siklus 2 menjadi $79 \%$. 
Tabel 8. Perolehan prosentase padaaspek keaktifan, perhatian, partisipasi,dan presentasi siswa dalam proses belajar dari siklus 1 dan siklus2

\begin{tabular}{|c|c|c|c|}
\hline \multirow[t]{2}{*}{ Data proses } & \multicolumn{2}{|c|}{$\begin{array}{l}\text { Prosentase } \\
\text { rata- rata per } \\
\text { siklus }\end{array}$} & \multirow[t]{2}{*}{ Ket } \\
\hline & S1 & S2 & \\
\hline $\begin{array}{l}\text { Aspek ketepatan prosedur pelaksanaan tindakan yang } \\
\text { dilakukan guru atau peneliti }\end{array}$ & $63 \%$ & $78 \%$ & Meningkat \\
\hline Aspek keaktifan siswa & $58 \%$ & $61 \%$ & Meningkat \\
\hline Aspek perhatian siswa & $76 \%$ & $85 \%$ & Meningkat \\
\hline Aspek partisipasi siswa & $73 \%$ & $73 \%$ & Tetap \\
\hline Aspek presentasi siswa & $73 \%$ & $78 \%$ & Meningkat \\
\hline Aspek Hasil Belajar & $53 \%$ & $79 \%$ & Meningkat \\
\hline Rata-rata & $69 \%$ & $73 \%$ & Meningkat \\
\hline
\end{tabular}

Meningkatnya aktivitas belajar siswa kelas VIII-G di SMP Negeri 2 Jatinangor Kabupaten Sumedang dalam proses belajar mengajar didukung oleh meningkatnya aktivitas guru dalam mempertahankan dan meningkatkan suasana pembelajaran yang mengarah pada pembelajaran kooperatif tipe Jigsaw. Guru intensif membimbing siswa saat siswa mengalami kesulitan dalam proses belajar mengajar dapat dilihat dari hasil observasi aktivitas guru dalam proses belajar mengajar meningkat 15 poin atau $15 \%$ dari $63 \%$ pada siklus pertama menjadi $78 \%$ pada siklus kedua

\section{KESIMPULAN}

Berdasarkan hasil penelitian dan pembahasan yang telah diuraikan pada bab sebelumnya, maka dapat diambil kesimpulan bahwa penerapan kombinasi pendekatan pembelajaran kooperatif tipe Jigsaw dan media benda asli dapat meningkatkan aktivitas belajar siswa kelas VIII-G di SMP Negeri 2 Jatinangor Kabupaten Sumedang terhadap materi ajar bangun ruang sisi datar dalam pelajaran matematika, kegiatan pembelajaran dengan menggunakan metode pembelajaran kooperatif dapat melatih siswa mendengarkan pendapat orang lain dan merangkum pendapat atau temuan- temuan dalam bentuk tulisan. Tugas-tugas kelompok memacu siswa untuk bekerja sama, saling membantu satu sama lain dalam mengintegrasikan pengetahuanpengetahuan baru dengan pengetahuan yang telah dimilikinya. Hasil penelitian ini sejalan dengan temuan yang diperoleh Kilic (2008); Widiastini, dkk (2014); Liando (2014); Kurniawati, dkk (2017).

Pembelajaran kooperatif tipe Jigsaw dapat meningkatkan kegiatan belajar siswa hal ini dapat dilihat dari hasil observasi memperlihatkan bahwa terjadi peningkatan keaktifan siswa yang pada siklus ke-1 hanya rata-rata $58 \%$ menjadi $61 \%$ pada siklus ke 2. Dari hasil observasi memperlihatkan bahwa juga terjadi peningkatan aktivitas siswa dalam hal ini rata-rata untuk aspek partisipasi tidak mengalami peningkatan yaitu pada siklus ke-1 rata-rata $73 \%$ pada siklus 2 juga tetap $73 \%$. Namun untuk aspek penguasaan siswa terhadap materi pembelajaran dalam hal ini bangun ruang sisi datar menunjukkan peningkatan. Hal ini dapat ditunjukkan dengan rata-rata hasil belajar pada siklus ke-1 rata-ratanya 53 atau 53\% menjadi 79 atau $79 \%$ pada siklus ke2 , kemudian aspek presentasi siswa setelah melakukan diskusi pada siklus 1 hanya 73 $\%$ meningkat pada siklus 2 menjadi $78 \%$. 


\section{DAFTAR RUJUKAN}

Arikunto, S. (2005). Pendidikan Tindakan Kelas. Jakarta: Bumi Aksara.

Darmawan, D., \& Sastrawijaya, Y. (2017) Peningkatan hasil belajar perakitan computer SMK Dinamika Pembangunan 1 Jakarta kelas X Teknik Komputer Jaringan dengan menggunakan model pembelajaran kooperatif tipe jigsaw. Jurnal Pinter Uol 1 No 2 desember 2017

Djamarah, S. B. (2002). Strategi Belajar Mengajar. Jakarta. PT Rineka Cipta.

Hamalik, O. (2008). Kurikulum dan Pembelajaran. Jakarta: Rineka Cipta.

Kurniawati, K. R. A., Budiyono., \& Saputro, D. R. S. (2017). Penerapan Model Pembelajaran Kooperatif Tipe Jigsaw dan NHT Ditinjau dari Kecerdasan Interpersonal Siswa Pada Pokok Bahasan Bangun Ruang Sisi Datar. Jurnal Pendidikan Matematika, Vol: 11, No:1.

Liando, M. R. (2014). Penerapan model pembelajaran kooperatif tipe jigsaw untuk meningkatkan hasil belajar. Jurnal Ilmiah Cisoc (Kajian Rumpun Pendidikan Ilmu Sosial) Volume 1 No. 01, 77 - 88.

Lie, A. (2008). Metode Belajar Kooperatif. Jakarta: PT.Bumi Aksara.

Luta, G. (2016). Media kongkret adalah.... [online] diakses pada http://sampaijumapalagi.blogspot.com/2016/07/ media-konkret-adalah.html

Mulyasa. E. (2005). Kurikulum Berbasis Kompetensi Konsep Karakteristik dan Implementasi. Bandung: Remaja Rosda Karya.

Sudjana., \& Rivai. (2005). Media Pengajaran. Jakarta: Sinar Baru.

Trisdiono, H., \& Zuwanti, I. (2017). Strategi Implementasi Model Pembelajaran Kooperatif Tipe Jigsaw Di Kelas IV Sekolah Dasar. Premiere Educandum 7(2) 95 - 103 [online] diakses pada http://e-journal.unipma. ac.id/index.php/PE DOI: 10.25273/pe.v7i2.1468

Wakil Menteri Pendidikan dan Kebudayaan R. I. (2014). Konsep dan Implementasi Kurikulum 2013 Paparan Bidang Pendidikan. KEMENTERIAN PENDIDIKAN DAN KEBUDAYAAN. Jakarta, [online] diakses pada https://www.kemdikbud.go.id/kemdikbud/dokumen/Paparan/Paparan\%20Wamendik.pdf

Widiastini, M., Kusmariyatni, N., \& Arini, N. W. (2014). Keefektifan model pembelajaran kooperatif tipe jigsaw untuk meningkatkan hasil belajar IPS Siswa kelas $V$. Journal Mimbar PGSD Universitas Pendidikan Ganesha Jurusan PGSD Vol: 2 No: 1.

Yoshida, M. (2018). Communication Jigsaw: A Teaching Method that Promotes Scholarly Communication. Masami Yoshida Chiba University. Chiba. [online] diakses pada https://doi.org/10.3991/ijet.v13i10.8850

Yoshida, M. (2017). Communication in graphs. Proocedings International Conference on Education and Learning, Tokyo. [online] diakses pada http://icel2017.globalconf.org/site/userdata/1137/Program/ICEL_Full_ Papers.pdf. 